\title{
Enhanced Symbol
}

National Cancer Institute

\section{Source}

National Cancer Institute. Enhanced Symbol. NCI Thesaurus. Code C45560.

This is a modification to the original GO database. For many UniProt records, this field is the gene symbol for the specified gene_product. For all other cases, it is the same as the symbol field. (GoMiner) 